\section{Characteristics of the environmental microscale and walking and bicycling for transportation among adults in Curitiba, Paraná State, Brazil}

\author{
Características da microescala do ambiente, \\ caminhada e uso de bicicleta no deslocamento \\ em adultos de Curitiba, Paraná, Brasil
}

\section{Características de una microescala ambiental y pasear, montar en bicicleta, como forma de transporte en una población adulta de Curitiba, Estado de Paraná, Brasil}

\author{
Adalberto Aparecido dos Santos Lopes 1,4 \\ Marilson Kienteka 1,4 \\ Rogério César Fermino 2,4 \\ Rodrigo Siqueira Reis 1,3,4
}

doi: 10.1590/0102-311Xe00203116

\begin{abstract}
The aim of this study was to analyze the association between the characteristics of the built and social and environmental microscale and walking and bicycling for transportation in adults in Curitiba, Paraná State, Brazil. A crosssectional study was performed in 2009 with a household survey that included 1,419 adults. Objective evaluation of environment was performed on the resident's street segments, using an instrument for systematic observation consisting of six dimensions: "land use", "public transportation", "streetscape", "conditions and aesthetics", "places for walking and bicycling", and "social environment". The score for each dimension was obtained as the sum of positive items related to physical activity. The items for "public transportation" ( $\geq 1$ items) and "places for walking and bicycling on the streets" ( $\geq 3$ items) were dichotomized, while the scores for the other items were classified in tertiles. Walking and bicycling for transportation were assessed with the International Physical Activity Questionnaire (IPAQ). The data were analyzed using multilevel Poisson regression. Medium "streetscape" score was inversely associated with walking $\geq 150 \mathrm{~min} /$ week $(P R=0.60 ; 95 \% C I: 0.40-0.91 ; \mathrm{VPC}=12 \%)$ and bicycling (PR $=0.54 ; 95 \% \mathrm{CI}: 0.29-0.99 ; \mathrm{VPC}=60 \%)$. In conclusion, only "streetscape" was associated with walking and bicycling for transportation in adults.
\end{abstract}

Controlled Environment; Motor Activity; Walking; Bicycling

\author{
Correspondence \\ A. A. S. Lopes \\ Grupo de Pesquisa em Atividade Física e Qualidade de Vida, \\ Pontifícia Universidade Católica do Paraná \\ Rua Imaculada Conceição 1155, Curitiba, PR 80215-901, \\ Brasil. \\ aadalberto@hotmail.com \\ 1 Programa de Pós-graduação em Educação Física, Universidade \\ Federal do Paraná, Curitiba, Brasil. \\ 2 Programa de Pós-graduação em Educação Física, Universidade \\ Tecnológica Federal do Paraná, Curitiba, Brasil. \\ 3 Brown School, Washington University in St. Louis, St. Louis, \\ U.S.A. \\ 4 Grupo de Pesquisa em Atividade Física e Qualidade de Vida, \\ Pontifícia Universidade Católica do Paraná, Curitiba, Brasil.
}




\section{Introduction}

Physical inactivity is a leading cause of death worldwide, with serious health problems, notably in low and middle-income countries 1 . This can be partly attributed to the increase in motor vehicles, chaotic urbanization, and precarious public safety and security that affect the way people commute on a daily basis 2,3,4. These and other characteristics have been widely studied at different scales of influence by the built environment in cities (micro, meso, and macro), especially the scales related to transportationrelated physical activity 4,5,6,7. Such characteristics include land use, street layout, presence and quality of sidewalks and bike lanes, access to public transportation, aesthetics, and public safety and security 4,6,7,8.

Evidence points to an association between variables in the perceived 5,9,10 and built environment 5,9,11,12 and transportation-related physical activity. Other studies have shown the positive effect of environmental changes on commuting behavior 12,13,14,15. However, a large share of the evidence comes from studies in high-income countries, which may not represent the urban and sociocultural characteristics of lower-income countries like those of Latin America 3,6,7.

In Brazil, different methodologies have been used to explore the association between variables from the built environment, such as "walkability" and transportation-related physical activity in adults $3,7,16,17,18,19$, while several characteristics vary according to the neighborhood's socioeconomic level 20,21. However, a recent review failed to identify studies that used systematic observation of environment for this evaluation in adults 19 . Thus, the lack of precise and detailed information on the variables in the built and social microscale raises an important question for investigation in Brazilian cities 8,22.

Certain objective measures can thus contribute to a better understanding of the relationship between cities' structure and physically active commuting 23,24. Data from the environmental microscale allow a detailed description of conditions in the quality of sidewalks, aesthetics, access to public transportation, lighting, and others that can be modified at low cost and in less time when compared to macroscale attributes, generally identified through geoprocessing data 5,8 .

Streetscape auditing is thus a potential option for obtaining microscale data, due to its low costs and the potential for producing precise details on urban variables 5,8. The objectivity of the measures requires clear protocols, comprehensive auditing items, and the possibility of capturing the environment's characteristics, which are dynamic, portraying the population's daily reality and potentially affecting individual choices as to mode of transportation 25,26 . The aim of this study was thus to analyze the association between the characteristics of the built and social environmental microscale and walking and bicycling as modes of transportation for adults in Curitiba, Paraná State, Brazil.

\section{Material and methods}

\section{Study design, location, and ethical issues}

This was a cross-sectional observational study using a household survey. The data are part of a research project in Curitiba, capital of Paraná State, in 2009. The project's principal objective was to assess the health characteristics, leisure-time habits, and physical activities of adults residing near the city's parks. The study was approved by the Institutional Review Board of the Federal University of Pelotas (case review 005/2008).

\section{Selection of sites and households}

In order to enhance the variability of socioeconomic status and characteristics of the built environment, eight urban parks were selected with different structures for physical activities, located in different areas of the city. The neighborhoods were classified in four groups: (1) high environmental quality and high socioeconomic status, (2) high environmental quality and low socioeconomic status, (3) low environmental quality and high socioeconomic status, and (4) low environmental quality and low socioeconomic status. Further details on the classification and selection criteria for the sites have been published elsewhere 27,28 . 
The households were selected from a 500-meter buffer around each of the eight parks, generated with the ArcGIS software (http://www.esri.com/software/arcgis/index.html). This distance has been adopted in similar studies 23 and considers a walking distance of five to 10 minutes from home to the park 27 . All street segments inside this radius $(n=1,899)$ were assessed to identify those with eligible households. One household was selected per segment, based on a random numbers table generated with the EpiInfo software (Centers for Disease Control and Prevention, Atlanta, USA). In all, 1,538 street segments with households were tallied. However, 361 (29\%) did not have happen to have households and were thus excluded from the analysis.

\section{Selection of participants and data collection}

One resident per household was randomly selected based on the inclusion criteria of adult age $(\geq 18$ years), no physical limitations, and having lived in the neighborhood for at least a year. Interviews were conducted in $95 \%$ of the eligible segments $(n=1,461)$, and in $5 \%$ of the remaining segments there were no eligible residents. The refusal rate was $8 \%(n=121)$, and quality control was performed in $13 \%$ of the interviews via telephone contact to verify the date and time of the interview and to confirm some key study variables.

\section{Dependent variables}

Walking and bicycling for transportation during a normal week were assessed with the International Physical Activity Questionnaire (IPAQ), long version 29. Variables were calculated as the ratio between weekly frequency and mean daily amount for each activity. Based on the literature 23, walking was operationalized as two different outcomes according to weekly amount ( $\geq 10 \mathrm{~min} /$ week" and " $\geq 150 \mathrm{~min} /$ week"), while bicycling was categorized as $\geq 10 \mathrm{~min} /$ week.

\section{Independent variables}

Objective evaluation of the environment used an instrument for systematic observation of the streetscape. The Inventory for the Evaluation of the Community Environment Related to Physical Activity (ICAF in Portuguese) was translated from the Active Neighborhood Checklist 26 and adapted to the Brazilian context, showing an inter-evaluator agreement of $85-98 \% 30$.

The items comprise the community environmental microscale, and the instrument consists of various characteristics, grouped in six dimensions: land use, public transportation, streetscape, conditions and aesthetics, places for walking and cycling, and social environment. A total of 105 items were assessed, and variables were grouped according to the dimensions of the built and social environment suggested in the original instrument, which considers the quantity, variety, and quality of the attributes related to physical activities 30 .

In the "land use" dimension, we evaluated occupation of the lots (45 items), "public transportation" included taxi stands, bus stops, and Bus Rapid Transit on one or both sides of the street segment ( 3 items). "Streetscape" assessed structures for slowing traffic or facilitating safe street crossings for pedestrians, such as speed limits and pedestrian lanes and signs (14 items). The "conditions and aesthetics" dimension included public improvements on the street segment, trash cans, and benches, versus signs of vandalism and graffiti (14 items). The dimension "places for walking and cycling" identified characteristics of the street and sidewalk that could hinder or facilitate walking or bicycling, such as obstacles, marked lanes, and signs, plus width of the sidewalks (sidewalks: 10 items; streets: 5 items). Finally, the "social environment" dimension assessed positive aspects like police presence, people engaged in physical activities and/ or conversing on the streets, versus negative characteristics such as people arguing or fighting, stray dogs and other animals, panhandlers, illegal parking attendants, and drunkards (12 items). The presence of items with a potential negative association with walking and cycling was recoded from "1" to "0" (e.g., dead-end streets, etc.)

In order to characterize the environment of the street segments, the attributes for each dimension were tallied and classified at three levels of quality by tertiles: low (1st tertile), medium ( $2^{\text {nd }}$ tertile), and high (3rd tertile). However, the items public transportation and places for walking and bicycling on streets 
showed low frequency of attributes, so we opted to analyze them dichotomously ( 0 items versus $\geq 1$ items and $0-2$ items versus $\geq 3$ items, respectively).

\section{- Individual variables}

Based on the conceptual model proposed by Saelens et al. ${ }^{9}$, some individual variables were identified that might confound the association between the variables in the built and social environment and the target outcomes: sex, age bracket, marital status, socioeconomic status, nutritional status, self-rated health, self-rated quality of life, perceived crime in the neighborhood, number of motor vehicles in the household, and use of public transportation. For example, female gender is positively associated with walking $\geq 10 \mathrm{~min} /$ week, but inversely associated with bicycling as transportation 23 . Meanwhile, vehicle ownership is inversely associated with the three outcomes analyzed in the current study 23 . These and other variables were identified, measured, and tested as possible covariates. The description of these measures and the way they are categorized are discussed next.

Sex (male, female) was recorded, age bracket was classified in three categories (18-39.9 years, 40-59.9 years, $\geq 60$ years), and marital status categorized as single or married. Socioeconomic status was assessed using the questionnaire of the Brazilian Association of Market Research Companies (ABEP) 31, and individuals were classified in three levels: low (classes C, D, and E), medium (class B), and high (class A).

Nutritional status was obtained from self-reported weight and height, and participants were classified as "normal weight" and "excess weight", according to body mass index. Self-rated health and quality of life were assessed with the World Health Organization Quality of Life (WHOQOL) scale, with answers according to a five-point Likert scale ${ }^{32}$. Self-rated health was assessed with the question, "Are you satisfied with your health?" (very dissatisfied, dissatisfied, neither satisfied nor dissatisfied, satisfied, very satisfied). For analytical purposes, the first three categories were grouped and operationalized as "negative self-rated health" and the other two as "positive self-rated health". Self-rated quality of life was assessed with the question, "How do you rate your quality of life?" (very bad, bad, neither bad nor good, good, and very good). The first three categories were operationalized as "negative self-rated quality of life" and the other two as "positive self-rated quality of life". Finally, perceived crime was assessed with the question, "Are there many crimes in your neighborhood?", with the dichotomous (no, yes) answer from the Neighborhood Environment Walkability Scale (NEWS) 33.

The number of motor vehicles in the household was assessed with the ABEP questionnaire 31 and operationalized in three categories $(0,1$, and $\geq 2)$. Use of public transportation was assessed with the question: "How many days a week do you use the city's public transportation?" (0 to 7 days), and the variable was operationalized in three categories ( 0 days, 1-2 days/week, and $\geq 3$ days/week). The principal means of daily transportation was assessed to characterize the participants, who could choose one of eight possible answers: car, public bus, walking, motorcycle, bicycle, private (company) bus, taxi, and other.

\section{Data analysis}

Multilevel Poisson regression was used to test the association between the variables of the built and social environment and walking and bicycling for transportation. Since the study design took into account the sample selection considering the eight parks as the primary sampling units, multilevel random intercept modeling was used to consider the cluster effect between the sampling units. The variance partition coefficient (VPC) was calculated for each combination of outcome and exposure, indicating the values of the constant and the proportion of variance attributed to the place level and the variation between individuals from the same location.

We first tested the association between the individual variables and the study's dependent variables. This allowed identifying variables that were potentially associated with each outcome $(\mathrm{p}<0.20)$ and that could be kept for analysis in the adjusted model. To construct the final multilevel regression model, we analyzed the association between the characteristics of the built and social environment and the transportation variables, adjusted for individual variables that presented $p<0.20$. The analyses were performed with the Stata 12.0 software (StataCorp LP, College Station, USA), using the xtmepoisson command, with significance kept at $5 \%$. 


\section{Results}

Of the 1,461 interviewees, 42 were excluded due to lack of complete data on some target variable, resulting in a final sample of 1,419 individuals (Table 1). The majority of the participants were female (63.6\%), 40-59 years of age (45.8\%), married (57.4\%), with medium socioeconomic status (49.8\%), with normal nutritional status (51.7\%), and with positive self-rated health (71.6\%) and quality of life (73.9\%), and with low perception of crimes in neighborhood (53.3\%). In addition, $62.4 \%$ of the participants reported using public transportation and $76.2 \%$ had at least one motor vehicle in the household. The principal means of daily transportation was by car (46.7\%), followed by public bus (34.3\%) and walking (12.9\%) (Table 1).

As for the variables in the built and social environment, the highest proportion of participants lived on street segments with medium-quality land use (41.2\%), public transportation (84.5\%), low-quality streetscape (60.4\%), low aesthetic quality (44.7\%), few favorable items on places for walking and bicycling on the streets (0-2 items: $79.6 \%$ ), and medium quality of the social environment (40.5\%). In addition, $69.1 \%$ of participants spent less time walking for transportation ( $\geq 10 \mathrm{~min} /$ week), while $20.3 \%$ walked for transportation at the recommended levels (150min/week), and only $9 \%$ reported bicycling for transportation at low levels ( $\geq 10 \mathrm{~min} /$ week) (Table 1$)$.

Table 2 shows the association between individual variables and walking and bicycling. Socioeconomic status $(\mathrm{p}<0.05)$ and number of motor vehicles $(\mathrm{p}<0.001)$ were inversely associated with walking $\geq 10 \mathrm{~min} /$ week, while weekly use of public transportation was positively associated $(\mathrm{p}<0.001)$ and married marital status was inversely and potentially associated with this outcome $(\mathrm{p}<0.20)$. Socioeconomic status, number of motor vehicles, and rate of weekly use of public transportation were associated with walking $\geq 150 \mathrm{~min} /$ week $(\mathrm{p}<0.001)$, while age bracket and marital status were potentially associated with this outcome $(\mathrm{p}<0.20)$. Sex, age bracket, self-rated health, perceived crime in the neighborhood, and rate of weekly use of public transportation showed significant association with bicycling $(\mathrm{p}<0.05)$, while self-rated quality of life and number of motor vehicles in the household were potentially associated with this outcome $(\mathrm{p}<0.20)$.

In the bivariate association between the environmental variables and the outcomes (Table 3), medium streetscape was inversely associated with walking $\geq 150 \mathrm{~min} /$ week (prevalence ratio $-\mathrm{PR}=0.62 ; 95 \% \mathrm{CI}$ : 0.41-0.92) and bicycling ( $\mathrm{PR}=0.53$; 95\%CI: 0.29-0.97). No significant values were observed in the test for trend among the categories of target variables.

After adjusting for possible confounding (Table 4), medium streetscape was associated with walking $\geq 150 \mathrm{~min} /$ week $(\mathrm{PR}=0.60$; 95\%CI: 0.40-0.91; $\mathrm{VPC}=12 \%)$ and bicycling (PR = 0.54; 95\%CI: 0.29-0.99; $\mathrm{VPC}=60 \%$ ). No significant values were found for the test for trend between target variables.

\section{Discussion}

This is the first study in Brazil to explore the association between characteristics of the built and social environment, obtained by systematic and direct observation of the environment, and walking and bicycling for transportation in adults. The methodology allowed a geographic representation of the places in neighborhoods with different environmental and social attributes for physical activity, besides obtaining and objectively measuring quantitative and qualitative attributes of the built and social environment that are not possible to identify in data obtained with geoprocessing or perception of the environment 24 . These are thus the current study's strengths and innovative characteristics. Streetscape was the only score inversely associated with walking greater than $150 \mathrm{~min} /$ week and bicycling.

A recent study in Recife, Pernambuco State, Brazil 30, evaluated the same attributes of the built and social environment around schools and found that public transportation, social environment, and overall environmental score were related to active commuting to school by preschool children (3-5 years). Two studies tested the association between the environment's characteristics (by systematic observation) and walking and bicycling in adults 8,25. However, these studies were done in cities in the United States, where the characteristics of the environment differ greatly in comparison to Brazilian cities 34 . For example, a multicenter study in 14 cities in 10 countries showed that the density of street intersections and mixed land use were greater in Curitiba, than in cities in New Zealand and the United States 34 . These variables, among others, are important predictors of walking and bicycling for transportation 5,9,34. 


\section{Table 1}

Description of individual and environmental variables, transportation-related physical activity, and means of transportation in adults. Curitiba, Paraná State, Brazil, $2009(N=1,419)$.

\begin{tabular}{|c|c|c|}
\hline Categories & $\mathbf{n}$ & $\%$ \\
\hline \multicolumn{3}{|c|}{ Individual variables } \\
\hline \multicolumn{3}{|c|}{ Gender } \\
\hline Male & 517 & 36.4 \\
\hline Female & 902 & 63.6 \\
\hline \multicolumn{3}{|c|}{ Age bracket (years) [5 missing] } \\
\hline $18-39$ & 587 & 41.5 \\
\hline $40-59$ & 647 & 45.8 \\
\hline$\geq 60$ & 180 & 12.7 \\
\hline \multicolumn{3}{|l|}{ Marital status } \\
\hline Single & 604 & 42.6 \\
\hline Married & 815 & 57.4 \\
\hline \multicolumn{3}{|c|}{ Socioeconomic status [8 missing] } \\
\hline Low & 532 & 37.7 \\
\hline Medium & 702 & 49.8 \\
\hline High & 177 & 12.5 \\
\hline \multicolumn{3}{|c|}{ Nutritional status [4 missing] } \\
\hline Normal & 731 & 51.7 \\
\hline Excess weight & 684 & 48.3 \\
\hline \multicolumn{3}{|l|}{ Self-rated health } \\
\hline Negative & 403 & 28.4 \\
\hline Positive & 1,016 & 71.6 \\
\hline \multicolumn{3}{|c|}{ Self-rated quality of life } \\
\hline Negative & 370 & 26.1 \\
\hline Positive & 1,049 & 73.9 \\
\hline \multicolumn{3}{|c|}{ Perceived crime in neighborhood [1 missing] } \\
\hline No & 756 & 53.3 \\
\hline Yes & 662 & 46.7 \\
\hline \multicolumn{3}{|c|}{ Number of motor vehicles in household [6 missing] } \\
\hline 0 & 336 & 23.8 \\
\hline 1 & 669 & 47.3 \\
\hline$\geq 2$ & 408 & 28.9 \\
\hline \multicolumn{3}{|c|}{ Use of public transportation (days/week) } \\
\hline 0 & 533 & 37.6 \\
\hline $1-2$ & 422 & 29.7 \\
\hline$\geq 3$ & 464 & 32.7 \\
\hline \multicolumn{3}{|c|}{ Environmental variables } \\
\hline \multicolumn{3}{|c|}{ Land use [1 missing] } \\
\hline Low & 483 & 34.1 \\
\hline Medium & 584 & 41.2 \\
\hline High (3rd tertile) & 351 & 24.8 \\
\hline \multicolumn{3}{|c|}{ Public transportation } \\
\hline 0 items & 220 & 15.5 \\
\hline$\geq 1$ items & 1,199 & 84.5 \\
\hline \multicolumn{3}{|c|}{ Streetscape [1 missing] } \\
\hline Low & 857 & 60.4 \\
\hline Medium & 219 & 15.4 \\
\hline High (3rd tertile) & 342 & 24.1 \\
\hline
\end{tabular}

(continues) 
Table 1 (continued)

Description of individual and environmental variables, transportation-related physical activity, and means of transportation in adults. Curitiba, Paraná State, Brazil, 2009 ( $N=1,419)$.

\begin{tabular}{|c|c|c|}
\hline Categories & $\mathbf{n}$ & $\%$ \\
\hline \multicolumn{3}{|l|}{ Environmental variables } \\
\hline \multicolumn{3}{|l|}{ Conditions and aesthetics } \\
\hline Low & 635 & 44.7 \\
\hline Medium & 364 & 25.7 \\
\hline High (3rd tertile) & 420 & 29.6 \\
\hline \multicolumn{3}{|c|}{ Places for walking and bicycling } \\
\hline \multicolumn{3}{|l|}{ Sidewalks } \\
\hline Low & 494 & 34.8 \\
\hline Medium & 485 & 34.2 \\
\hline High (3rd tertile) & 440 & 31.0 \\
\hline \multicolumn{3}{|l|}{ Streets } \\
\hline 0-2 items & 1,130 & 79.6 \\
\hline$\geq 3$ items & 289 & 20.4 \\
\hline \multicolumn{3}{|l|}{ Social environment } \\
\hline Low & 492 & 34.7 \\
\hline Medium & 575 & 40.5 \\
\hline High (3rd tertile) & 352 & 24.8 \\
\hline \multicolumn{3}{|c|}{ Transportation-related physical activity } \\
\hline \multicolumn{3}{|l|}{ Walking I [2 missing] } \\
\hline 0-9min/week & 438 & 30.9 \\
\hline$\geq 10 \mathrm{~min} /$ week & 979 & 69.1 \\
\hline \multicolumn{3}{|l|}{ Walking II [2 missing] } \\
\hline 0-149min/week & 1,130 & 79.7 \\
\hline$\geq 150 \mathrm{~min} /$ week & 287 & 20.3 \\
\hline \multicolumn{3}{|l|}{ Bicycling [1 missing] } \\
\hline 0-9min/week & 1,290 & 91.0 \\
\hline$\geq 10 \mathrm{~min} /$ week & 128 & 9.0 \\
\hline \multicolumn{3}{|c|}{ Main mode of transportation [13 missing] } \\
\hline Car & 657 & 46.7 \\
\hline Public bus & 482 & 34.3 \\
\hline Walking & 181 & 12.9 \\
\hline Motorcycle & 33 & 2.3 \\
\hline Bicycle & 31 & 2.2 \\
\hline Private bus (company) & 14 & 1.0 \\
\hline Taxi & 2 & 0.1 \\
\hline Other & 6 & 0.4 \\
\hline
\end{tabular}

Medium streetscape reduced by $41 \%$ and $46 \%$, respectively, the likelihood of walking $\geq 150 \mathrm{~min} /$ week and bicycling. These results differ from a study in the US cities of Seattle, San Diego, Baltimore, and Washington DC, where the overall streetscape score was positively associated with weekly frequency of active commuting (walking + bicycling) 34 . The inverse association shown in the current study may have several explanations. First, the majority of the streets in the selected neighborhoods show low commercial density, so residents do not need to walk or pedal to local shops on a daily basis 9 . In fact, in Curitiba a positive association was found between the proportion of business districts close to the household and walking for transportation 23 . Second, proximity to parks may be associated with use of these places for leisure-time physical exercise only 27,35, and not for transportation. Third, since parks may pose natural barriers to "short" errands on foot or bicycle to neighborhood 


\section{Table 2}

Multilevel bivariate association between individual variables and walking and bicycling for transportation in adults. Curitiba, Paraná State, Brazil, $2009(N=1,419)$

\begin{tabular}{|c|c|c|c|c|c|c|}
\hline & \multicolumn{2}{|c|}{$\begin{array}{c}\text { Walking I } \\
\geq 10 \mathrm{~min} / \text { week }\end{array}$} & \multicolumn{2}{|c|}{$\begin{array}{c}\text { Walking II } \\
\geq 150 \mathrm{~min} / \text { week }\end{array}$} & \multicolumn{2}{|c|}{$\begin{array}{c}\text { Bicycling } \\
\geq 10 \mathrm{~min} / \text { week }\end{array}$} \\
\hline & PR & $95 \% \mathrm{Cl}$ & PR & $95 \% \mathrm{Cl}$ & PR & $95 \% \mathrm{Cl}$ \\
\hline \multicolumn{7}{|l|}{ Gender } \\
\hline Female & 1.00 & * & 1.00 & * & 1.00 & $* \star$ \\
\hline Male & 0.93 & $0.82-1.07$ & 0.98 & $0.77-1.25$ & 4.45 & $3.03-6.55$ \\
\hline \multicolumn{7}{|l|}{ Age bracket (years) } \\
\hline $18-39$ & 1.00 & * & 1.00 & $\star * \star$ & 1.00 & $\star \star$ \\
\hline $40-59$ & 0.99 & $0.86-1.14$ & 1.12 & $0.87-1.46$ & 0.67 & $0.47-0.96$ \\
\hline$\geq 60$ & 1.14 & $0.93-1.38$ & 1.40 & $0.99-1.98$ & 0.18 & $0.06-0.50$ \\
\hline \multicolumn{7}{|l|}{ Marital status } \\
\hline Single & 1.00 & $\star * *$ & 1.00 & 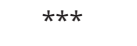 & 1.00 & * \\
\hline Married & 0.91 & $0.80-1.04$ & 0.79 & $0.62-1.00$ & 0.77 & $0.54-1.10$ \\
\hline \multicolumn{7}{|c|}{ Socioeconomic status } \\
\hline Low & 1.00 & \# & 1.00 & ** & 1.00 & * \\
\hline Medium & 0.87 & $0.75-1.00$ & 0.66 & $0.51-0.85$ & 0.97 & $0.67-1.41$ \\
\hline High & 0.68 & $0.54-0.87$ & 0.34 & $0.21-0.56$ & 0.58 & $0.29-1.15$ \\
\hline \multicolumn{7}{|l|}{ Nutritional status } \\
\hline Normal & 1.00 & * & 1.00 & * & 1.00 & * \\
\hline Excess weight & 1.01 & $0.89-1.14$ & 1.13 & $0.89-1.43$ & 0.82 & $0.57-1.16$ \\
\hline \multicolumn{7}{|l|}{ Self-rated health } \\
\hline Negative & 1.00 & * & 1.00 & * & 1.00 & \# \\
\hline Positive & 0.95 & $0.83-1.09$ & 0.97 & $0.75-1.26$ & 1.74 & $1.11-2.73$ \\
\hline \multicolumn{7}{|c|}{ Self-rated quality of life } \\
\hline Negative & 1.00 & * & 1.00 & * & 1.00 & $* * *$ \\
\hline Positive & 1.07 & $0.92-1.24$ & 1.03 & $0.78-1.35$ & 1.40 & $0.91-2.16$ \\
\hline \multicolumn{7}{|c|}{ Perceived crime in neighborhood } \\
\hline No & 1.00 & * & 1.00 & * & 1.00 & $\#$ \\
\hline Yes & 1.05 & $0.92-1.20$ & 1.02 & $0.80-1.29$ & 0.68 & $0.47-0.97$ \\
\hline \multicolumn{7}{|c|}{ Number of motor vehicles in household } \\
\hline 0 & 1.00 & ** & 1.00 & $* *$ & 1.00 & $\star * \star$ \\
\hline 1 & 0.84 & $0.72-0.98$ & 0.70 & 0.54-092 & 0.83 & $0.55-1.26$ \\
\hline$\geq 2$ & 0.71 & $0.60-0.85$ & 0.40 & $0.28-0.57$ & 0.72 & $0.45-1.17$ \\
\hline \multicolumn{7}{|c|}{ Use of public transportation (days/week) } \\
\hline 0 & 1.00 & $\star *$ & 1.00 & $* *$ & 1.00 & $\#$ \\
\hline $1-2$ & 1.40 & $1.19-1.64$ & 1.60 & $1-16-2.21$ & 1.67 & $1.07-2.60$ \\
\hline$\geq 3$ & 1.49 & $1.28-1.75$ & 2.43 & $1.81-3.27$ & 1.65 & $1.07-2.56$ \\
\hline
\end{tabular}

95\%Cl: 95\% confidence interval; PR: prevalence ratio.

* $p \geq 0.20$;

$* * p<0.001$;

$* * * p<0.20$

$\# p<0.05$.

shops and services, the high household vehicle ownership rate (76\%) may favor the use of vehicles for these errands 28 . In fact, some $50 \%$ of the interviewees reported using their car or motorcycle as their main means of daily transportation (Table 1). Finally, although the medium "streetscape" score indicates street segments with better characteristics which may facilitate walking (pedestrian crossings and lights, 
Multilevel bivariate association between quality/presence of environmental variables and walking and bicycling for transportation in adults. Curitiba, Paraná State, Brazil, 2009 ( $N=1,419)$.

\begin{tabular}{|c|c|c|c|c|c|c|}
\hline & \multicolumn{2}{|c|}{$\begin{array}{c}\text { Walking I } \\
\geq 10 \mathrm{~min} / \text { week }\end{array}$} & \multicolumn{2}{|c|}{$\begin{array}{c}\text { Walking II } \\
\geq 150 \mathrm{~min} / \text { week }\end{array}$} & \multicolumn{2}{|c|}{$\begin{array}{c}\text { Bicycling } \\
\geq 10 \mathrm{~min} / \text { week }\end{array}$} \\
\hline & PR & $95 \% \mathrm{Cl}$ & PR & $95 \% \mathrm{Cl}$ & PR & $95 \% \mathrm{Cl}$ \\
\hline \multicolumn{7}{|c|}{ Environmental variables } \\
\hline \multicolumn{7}{|c|}{ Land use (reference: low) } \\
\hline Medium & 1.08 & $0.92-1.25$ & 1.21 & $0.90-1.63$ & 1.14 & $0.75-1.72$ \\
\hline High & 1.12 & $0.94-1.35$ & 1.25 & $0.88-1.79$ & 1.24 & $0.78-1.97$ \\
\hline \multicolumn{7}{|c|}{ Public transportation (reference: 0 items) } \\
\hline$\geq 1$ items & 0.89 & $0.75-1.05$ & 0.86 & $0.64-1.17$ & 0.79 & $0.50-1.23$ \\
\hline \multicolumn{7}{|c|}{ Streetscape (reference: low) } \\
\hline Medium & 1.08 & $0.90-1.29$ & 0.62 & $0.41-0.92$ & 0.53 & $0.29-0.97$ \\
\hline High & 1.08 & $0.91-1.28$ & 0.93 & $0.67-1.30$ & 0.79 & $0.51-1.22$ \\
\hline \multicolumn{7}{|c|}{ Conditions and aesthetics (reference: low) } \\
\hline Medium & 1.00 & $0.85-1.18$ & 0.87 & $0.63-1.20$ & 1.10 & $0.72-1.68$ \\
\hline High & 1.06 & $0.89-1.26$ & 1.25 & $0.89-1.77$ & 0.94 & $0.60-1.46$ \\
\hline \multicolumn{7}{|c|}{ Places for walking and bicycling } \\
\hline \multicolumn{7}{|c|}{ Sidewalks (reference: low) } \\
\hline Medium & 1.02 & $0.87-1.19$ & 1.30 & $0.97-1.74$ & 0.89 & $0.59-1.34$ \\
\hline High & 0.99 & $0.84-1.18$ & 1.01 & $0.72-1.41$ & 0.76 & $0.48-1.19$ \\
\hline \multicolumn{7}{|c|}{ Streets (reference: 0-2 items) } \\
\hline$\geq 3$ items & 0.99 & $0.84-1.17$ & 1.08 & $0.80-1.46$ & 1.05 & $0.68-1.61$ \\
\hline \multicolumn{7}{|c|}{ Social environment (reference: low) } \\
\hline Medium & 1.02 & $0.88-1.19$ & 0.91 & $0.68-1.21$ & 0.84 & $0.55-1.27$ \\
\hline High & 1.06 & $0.89-1.26$ & 1.11 & $0.81-1.51$ & 1.09 & $0.70-1.69$ \\
\hline
\end{tabular}

95\% Cl: 95\% confidence interval; PR: prevalence ratio.

speed bumps, etc.), besides the previously reported relationship between purchasing power and vehicle ownership and use, the presence of bus stops on most of the segments (85\%) may also favor use of the latter means of transportation rather than walking and/or bicycling 23. The proportion of participants that reported using car, motorcycle, or public transportation was actually quite high (83\%) when compared to walking or bicycling (15\%) (Table 1).

In addition, the inverse relationship observed between "streetscape" and bicycling may be explained by the fact that some target items (speed bumps, pedestrian lights and crossings, number of lanes on the street segment, among others) represent barriers, which ends up hindering walking and bicycling ${ }^{36}$. For example, Hino et al. 23 used geoprocessing data and found that presence of stoplights on street segments can reduce by $73 \%$ the odds of bicycling as transportation among adults in Curitiba. In addition, speed bumps, radars, and speed limit signs may be present mostly on street segments with heavy vehicle traffic 37 . This characteristic, among others, may increase the perceived fear of accidents by bicyclists, reported in the literature as an important barrier to cycling 38 . In fact, only $2 \%$ of the interviewees reported bicycling as their principal means of daily transportation (Table 1).

Most of the items in the systematic observation of the built and social environment were not associated with walking or bicycling for transportation. However, Hoehner et al. 25 used the same instrument to evaluate street segments in 1,053 adults living within a 400-meter radius in two American cities (Saint Louis, Missouri, and Savannah, Georgia) and found that the number of streets with bus stops, trees, and other pedestrian amenities, as well as the number of persons seen engaged in physical activity (positive social environment) showed a positive association with walking and bicycling for transportation 25 . Despite the difference in the direction and/or absence of most of the associations, it is important to note 


\section{Table 4}

Adjusted multilevel association between quality/presence of environmental variables and walking and bicycling for transportation in adults. Curitiba, Paraná State, Brazil, 2009 ( $N=1,419)$.

\begin{tabular}{|c|c|c|c|c|c|c|}
\hline & \multicolumn{2}{|c|}{$\begin{array}{c}\text { Walking I } \\
\geq 10 \mathrm{~min} / \text { week * }\end{array}$} & \multicolumn{2}{|c|}{$\begin{array}{c}\text { Walking II } \\
\geq 150 \mathrm{~min} / \text { week ** }\end{array}$} & \multicolumn{2}{|c|}{$\begin{array}{c}\text { Bicycling } \\
\geq 10 \mathrm{~min} / \text { week ***}\end{array}$} \\
\hline & PR & $95 \% \mathrm{Cl}$ & PR & $95 \% \mathrm{Cl}$ & PR & $95 \% \mathrm{Cl}$ \\
\hline \multicolumn{7}{|c|}{ Environmental variables } \\
\hline \multicolumn{7}{|c|}{ Land use (ref: low) } \\
\hline Medium & 1.07 & $0.91-1.24$ & 1.18 & $0.87-1.59$ & 1.08 & $0.72-1.64$ \\
\hline \multirow[t]{2}{*}{ High } & 1.11 & $0.92-1.33$ & 1.19 & $0.83-1.70$ & 1.12 & $0.71-1.78$ \\
\hline & & $0.123(0.036) \#$ & & $0.385(0.104) \#$ & & $0.108(0.031) \#$ \\
\hline \multicolumn{7}{|c|}{ Public transportation (ref: 0 items) } \\
\hline \multirow[t]{2}{*}{$\geq 1$ items } & 0.89 & $0.75-1.06$ & 0.88 & $0.65-1.20$ & 0.75 & $0.48-1.17$ \\
\hline & & $0.133(0.038) \#$ & & $0.410(0.110) \#$ & & $0.105(0.030) \#$ \\
\hline \multicolumn{7}{|c|}{ Streetscape (ref: low) } \\
\hline Medium & 1.09 & $0.91-1.31$ & 0.60 & $0.40-0.91$ & 0.54 & $0.29-0.99$ \\
\hline \multirow[t]{2}{*}{ High } & 1.09 & $0.92-1.30$ & 0.96 & $0.69-1.34$ & 0.71 & $0.46-1.10$ \\
\hline & & $0.127(0.037) \#$ & & $0.462(0.123) \#$ & & $5.06(0.605) \#$ \\
\hline \multicolumn{7}{|c|}{ Conditions and aesthetics (ref: low) } \\
\hline Medium & 1.01 & $0.86-1.19$ & 0.87 & $0.62-1.21$ & 1.04 & $0.68-1.58$ \\
\hline \multirow[t]{2}{*}{ High } & 1.07 & $0.90-1.28$ & 1.20 & 0.84-1.70 & 0.83 & $0.54-1.28$ \\
\hline & & $0.127(0.037) \#$ & & $0.381(0.103) \#$ & & $0.000(0.000) \#$ \\
\hline \multicolumn{7}{|c|}{ Places for walking and bicycling } \\
\hline \multicolumn{7}{|c|}{ Sidewalks (ref: low) } \\
\hline Medium & 1.01 & $0.87-1.18$ & 1.28 & $0.95-1.72$ & 0.90 & $0.60-1.35$ \\
\hline \multirow[t]{2}{*}{ High } & 1.00 & $0.84-1.18$ & 0.99 & $0.71-1.40$ & 0.78 & $0.50-1.22$ \\
\hline & & $0.140(0.040) \#$ & & $0.426(0.114) \#$ & & $0.000(0.000) \#$ \\
\hline \multicolumn{7}{|c|}{ Streets (ref: 0-2 items) } \\
\hline \multirow[t]{2}{*}{$\geq 3$ items } & 1.01 & $0.86-1.20$ & 1.17 & $0.86-1.60$ & 0.92 & $0.60-1.42$ \\
\hline & & $0.139(0.040) \#$ & & $0.401(0.108) \#$ & & $0.080(0.023) \#$ \\
\hline \multicolumn{7}{|c|}{ Social environment (ref: low) } \\
\hline Medium & 1.02 & $0.87-1.19$ & 0.90 & $0.67-1.20$ & 0.83 & $0.55-1.25$ \\
\hline \multirow[t]{2}{*}{ High } & 1.03 & $0.87-1.23$ & 1.03 & $0.75-1.41$ & 0.91 & $0.58-1.42$ \\
\hline & & $0.133(0.038) \#$ & & $0.414(0.111) \#$ & & $0.084(0.024) \#$ \\
\hline
\end{tabular}

95\%Cl: 95\% confidence interval; PR: prevalence ratio.

* Adjusted for socioeconomic status, marital status, number of motor vehicles in household, and use of public transportation;

** Adjusted for age bracket, socioeconomic status, marital status, number of motor vehicles in household, and use of public transportation;

*** Adjusted for sex, age bracket, marital status, self-rated health and quality of life, crime in neighborhood, number of motor vehicles in household, and use of public transportation

\# Values for constant and variance partifition coefficient (VPC).

that the current study's findings are similar to those in the literature 5,9,23,25. Saelens et al. 5,9 highlight that cross-sectional studies tend to only show associations between variables from the built environment and transportation-related walking and/or bicycling. The lack of association may be attributed to the fact that this behavior may be influenced by other neighborhood predictors 5,9. For example, studies show that adults living in neighborhoods with high walkability and access to services are more likely to walk when compared to adults living in neighborhoods with the opposite such characteristics 17,21,24.

Some limitations should be addressed for an adequate interpretation and extrapolation of the current study's results. IPAQ shows low sensitivity for measuring transportation-related physical activity, since it captures high rates of such activity, leading to an underestimation of shorter such periods ( $\geq 10 \mathrm{~min} /$ week), which may have led to the lack of the target associations ${ }^{29}$. However, in Curitiba some items in 
the environment such as bus stops could be positively associated with less walking per week ( $\geq 10 \mathrm{~min} /$ week), since the distance to bus stops is short (average of 175 meters) 23 . The sample does not represent the city's entire adult population, since it was limited to individuals living in the vicinity of eight parks with the potential for recreational physical activities 27 . Some studies have suggested that the presence of parks in the neighborhood is associated with greater appreciation of the surrounding areas, which would in turn lead to better characteristics in the built environment and little variability in the indicators between places 39 . The scores on the items from the environment were calculated from the measurement of the variables observed on the street segments of the participants' households, so it was not possible to calculate an "environmental quality" score within an area that the individual might be exposed to or cross when walking or pedaling, for example a circular buffer or street network buffer (including sausage buffer and detailed trimmed buffer, both with $25 \mathrm{~cm}$ or $75 \mathrm{~cm}$ radius on either side of street and; detailed biffer) measuring 300, 500, or 1,000 meters 40 . Finally, the cross-sectional design limits the causal interpretation between variables.

\section{Conclusion}

Streetscape was inversely associated with walking and bicycling as modes of transportation.

Future experimental studies should be conducted in lower-income countries like Brazil to test the effects of environmental changes on walking and bicycling for transportation in adults. In addition, triangulation of methods in the same study (evaluation of the perception of the built environment, geoprocessing data, systematic observation of the built environment, use of Global Positioning System equipment and focus group interviews) can also add to the understanding of the relationship between the built environment and transportation-related physical activity in adults.

\section{Contributors}

A. A. S. Lopes participated in the data collection, initial study conception, data analysis, literature review, and writing and critical revision of the article in all its stages. M. Kienteka, participated in the data collection, initial study conception, and first draft of the article. R. C. Fermino participated in the data collection, initial study conception, literature review, and writing and critical revision of the article in all its stages. R. S. Reis was responsible for the research project's conception and coordination and participated in the critical revision of the article.

\section{Acknowledgments}

The authors wish to thank the members of the Research Group on Physical Activity and Quality of Life of the Pontifical Catholic University of Paraná (GPAQ/PUCPR) for their collaboration in the data collection. 


\section{References}

1. Lee I-M, Shiroma EJ, Lobelo F, Puska P, Blair SN, Katzmarzyk PT, et al. Effect of physical inactivity on major non-communicable diseases worldwide: an analysis of burden of disease and life expectancy. Lancet 2012; 380:219-29.

2. Monda KL, Gordon-Larsen P, Stevens J, Popkin BM. China's transition: the effect of rapid urbanization on adult occupational physical activity. Soc Sci Med 2007; 64:858-70.

3. Arango CM, Páez DC, Reis RS, Brownson RC, Parra DC, Barreto S, et al. Association between the perceived environment and physical activity among adults in Latin America: a systematic review. Int J Behav Nutr Phys Act 2013; 10:122.

4. Kerr J, Emond J, Badland H, Reis R, Sarmiento O, Carlson J, et al. Perceived neighborhood environmental attributes associated with walking and cycling for transport among adult residents of 17 cities in 12 countries: the IPEN study. Environ Health Perspect 2015; 124:290-8.

5. Saelens BE, Handy SL. Built environment correlates of walking: a review. Med Sci Sports Exerc 2008; 40(7 Suppl):S550-66.

6. Sallis JF, Bull F, Guthold R, Heath GW, Inoue S, Kelly P, et al. Progress in physical activity over the olympic quadrennium. Lancet 2016; 6736:1-12.

7. Bauman AE, Reis RS, Sallis JF, Wells JC, Loos RJF, Martin BW, et al. Correlates of physical activity: why are some people physically active and others not? Lancet 2012; 380:258-71.

8. Cain KL, Millstein RA, Sallis JF, Conway TL, Gavand KA, Frank LD, et al. Contribution of streetscape audits to explanation of physical activity in four age groups based on the Microscale Audit of Pedestrian Streetscapes (MAPS). Soc Sci Med 2014; 116:82-92.

9. Saelens BE, Sallis JF, Frank LD. Environmental correlates of walking and cycling: findings from the transportation, urban design, and planning literatures. Ann Behav Med 2003; 25:80-91.

10. Gebel K, Bauman AE, Petticrew M. The physical environment and physical activity: a critical appraisal of review articles. Am J Prev Med 2007; 32:361-9.

11. Grasser G, Van Dyck D, Titze S, Stronegger W. Objectively measured walkability and active transport and weight-related outcomes in adults: a systematic review. Int J Public Health 2013; 58:615-25.
12. McCormack GR, Shiell A. In search of causality: a systematic review of the relationship between the built environment and physical activity among adults. Int J Behav Nutr Phys Act 2011; 8:1-11.

13. Mayne SL, Auchincloss AH, Michael YL. Impact of policy and built environment changes on obesity-related outcomes: a systematic review of naturally occurring experiments. Obes Rev 2015; 16:362-75.

14. Fraser SDS, Lock K. Cycling for transport and public health: a systematic review of the effect of the environment on cycling. Eur J Public Health 2011; 21:738-43.

15. Kienteka M, Fermino R, Reis R. Fatores individuais e ambientais associados com o uso de bicicleta por adultos: uma revisão sistemática. Rev Bras Ativ Fís Saúde 2014; 19:12-24.

16. Reis RS, Hino AA, Parra DC, Hallal PC, Brownson RC. Bicycling and walking for transportation in three Brazilian cities. Am J Prev Med 2013; 44:9-17.

17. Rech CR, Reis RS, Hino AA, Hallal PC. Personal, social and environmental correlates of physical activity in adults from Curitiba, Brazil. Prev Med 2014; 58:53-7.

18. Florindo AA, Salvador EP, Reis RS. Physical activity and its relationship with perceived environment among adults living in a region of low socioeconomic level. J Phys Act Heal 2013; 10:563-71.

19. Belon AP, Nykiforuk C. Possibilities and challenges for physical and social environment research in Brazil: a systematic literature review on health behaviors. Cad Saúde Pública 2013; 29:1955-73.

20. Hino AAF, Rech CR, Gonçalves PB, Hallal PC, Reis RS. Projeto ESPAÇOS de Curitiba, Brasil: aplicabilidade de métodos mistos de pesquisa e informações georreferenciadas em estudos sobre a atividade física e ambiente construído. Rev Panam Salud Pública 2012; 32:226-33.

21. Reis RS, Hino AAF, Rech CR, Kerr J, Hallal PC. Walkability and physical activity: findings from Curitiba, Brazil. Am J Prev Med 2013; 45:269-75.

22. Moudon AV, Lee C. Walking and bicycling: an evaluation of environmental audit instruments. Am J Heal Promot 2003; 18:21-37. 
23. Hino AAF, Reis RS, Sarmiento OL, Parra DC Brownson RC. Built environment and physical activity for transportation in adults from Curitiba, Brazil. J Urban Health 2014; 91:446-62.

24. Hino AAF, Reis RS, Florindo AA. Ambiente construído e atividade física: uma breve revisão dos métodos de avaliação. Rev Bras Cineantropom Desempenho Hum 2010; 12:387-94.

25. Hoehner CM, Brennan Ramirez LK, Elliott MB, Handy SL, Brownson RC. Perceived and objective environmental measures and physical activity among urban adults. Am J Prev Med 2005; 28:105-16.

26. Brownson RC, Hoehner CM, Brennan LK, Cook RA, Elliott MB, Mcmullen KM. Reliability of two instruments for auditing the environment for physical activity. J Phys Act Health 2004;1:189-207.

27. Fermino RC, Reis RS, Hallal PC, Kaczynski AT. Who are the users of urban parks? a study with adults from Curitiba, Brazil. J Phys Act Health 2015; 12:58-67.

28. Rech C, Reis R, Hino AA, Rodriguez-Añez C, Fermino R, Gonçalves P, et al. Neighborhood safety and physical inactivity in adults from Curitiba, Brazil. Int J Behav Nutr Phys Act 2012; 9:72

29. Hallal PC, Gomez LF, Parra DC, Lobelo F, Mosquera J, Florindo AA, et al. Lessons learned after 10 years of IPAQ use in Brazil and Colombia. J Phys Act Health 2010; 7 Suppl 2:S259-64.

30. Melo EN, Barros M, Reis RS, Hino AAF, Santos CM, Farias Junior JC, et al. Is the environment near school associated with active commuting to school among preschoolers? Rev Bras Cineantropom Desempenho Hum 2013; 15:393-404.

31. Kamakura W, Mazzo JA. Critérios de estratificação e comparação de classificadores socioeconômicos no Brasil. RAE Revista de Administração de Empresas 2016; 56:55-70.

32. Fleck MPA, Louzada S, Xavier M, Chachamovich E, Vieira G, Santos L, et al. Aplicação da versão em português do instrumento abreviado de avaliação da qualidade de vida "WHOQOL-bref". Rev Saúde Pública 2000; $34: 178-83$
33. Malavasi LDM, Both J, Reis RS. Escala de mobilidade ativa no ambiente comunitário - NEWS Brasil: retradução e reprodutibilidade. Rev Bras Cineantropom Desempenho Hum 2007; 9:339-50.

34. Christiansen LB, Cerin E, Badland H, Kerr J, Davey R, Troelsen J, et al. International comparisons of the associations between objective measures of the built environment and transport-related walking and cycling: IPEN adult study. J Transp Health 2016; 3:467-78.

35. Fermino RC, Hallal PC, Reis RS. Frequência de uso de parques e prática de atividades físicas em adultos de Curitiba, Brasil. Rev Bras Med Esporte 2017; 23:264-70.

36. Dill J, Carr T. Bicycle commuting and facilities in major U.S. cities: if you build them, commuters will use them. Transportation Research Record: Journal of the Transportation Research Board 2003; 1828:116-23.

37. Chataway ES, Kaplan S, Nielsen TAS, Prato CG. Safety perceptions and reported behavior related to cycling in mixed traffic: a comparison between Brisbane and Copenhagen. Transportation Research Part F: Traffic Psychology and Behaviour 2014; 23:32-43.

38. Camargo EM, Fermino RC, Reis RS. Barriers and facilitators to bicycle use in adults: a systematic review. Rev Bras Ativ Fís Saúde 2015; 20:103-12.

39. Bedimo-Rung AL, Mowen AJ, Cohen DA. The significance of parks to physical activity and public health: a conceptual model. Am J Prev Med 2005; 28:159-68.

40. Frank LD, Fox EH, Ulmer JM, Chapman JE, Kershaw SE, Sallis JF, et al. International comparison of observation-specific spatial buffers: maximizing the ability to estimate physical activity. Int J Health Geogr 2017; 16:4 


\section{Resumo}

O objetivo deste estudo foi analisar a associação entre as características da microescala do ambiente construído e social com a caminhada e o uso da bicicleta no deslocamento em adultos de Curitiba, Paraná, Brasil. No ano de 2009 foi conduzido um estudo transversal com inquérito domiciliar em que participaram 1.419 adultos. A avaliação objetiva do ambiente foi realizada nos segmentos de rua dos moradores, com um instrumento de observação sistemática composto por seis dimensões: "uso do solo", "transporte público", "características das ruas", "condições e estética", "lugares para caminhar e andar de bicicleta" "ambiente social". $O$ escore de cada dimensão foi obtido pela soma dos itens positivos relacionados com a atividade física. Optou-se por dicotomizar os itens de "transporte público" ( $\geq 1$ itens) e "lugares para caminhar e andar de bicicleta nas ruas" ( $\geq 3$ itens), enquanto o escore dos demais foram classificados em tercis. A caminhada e o uso da bicicleta no deslocamento foram avaliados com o International Physical Activity Questionnaire. Os dados foram analisados com a regressão de Poisson multinível. Os resultados demostraram que o escore intermediário de "características das ruas" foi inversamente associado com a caminhada $\geq 150 \mathrm{~min} / \mathrm{sem}$ $(R P=0,60 ;$ IC95\%: 0, 40-0,91; $C P V=12 \%) e$ uso da bicicleta $(R P=0,54$; IC95\%: 0,29-0,99; $C P V=60 \%)$. Conclui-se que apenas as "características das ruas" foram associadas à caminhada e o uso da bicicleta no deslocamento em adultos.

Meio Ambiente Construído; Atividade Motora; Caminhada; Ciclismo

\section{Resumen}

Se El objetivo de este estudio ha sido analizar la asociación entre las características de la creación de una microescala social y ambiental con caminar y montar en bicicleta, como forma de transporte entre adultos en Curitiba, Estado de Paraná, Brasil. Se realizó un estudio transversal en 2009 con una encuesta a hogares que incluyó a 1.419 adultos. Se realizó una evaluación objetiva del entorno con segmentos de calle residenciales, usando un instrumento para la observación sistemática consistente en seis dimensiones: "uso de la tierra", "transporte público", "paisaje urbano", "condiciones y estética", "lugares para caminar y montar en bicicleta", y "entorno social". La puntuación para cada dimensión se obtuvo como la suma de items positivos relacionados con la actividad física. Los items para "transporte público" ( $\geq 1$ item) y "lugares para pasear y montar en bicicleta en las calles" ( $\geq 3$ items) fueron dicotomizados, mientras que las puntuaciones para los otros items fueron clasificadas en terciles. Andar y montar en bicicleta como transporte fueron evaluados con el International Physical Activity Questionnaire (IPAQ). Los datos se analizaron usando la regresión multinivel de Poisson. Una puntuación media en "paisaje urbano" estaba inversamente asociada con caminar $\geq 150 \mathrm{~min} / \mathrm{semana}$ ( $P R=0.60$; 95\%CI: 0.40-0.91; $C P V=12 \%)$ y montar en bicicleta $(P R=0.54$; 95\%CI: 0.29-0.99; CPV = 60\%). En conclusión, solamente "paisaje urbano" estaba asociado con caminar y montar en bicicleta para el transporte en adultos.

Medio Ambiente Controlado; Actividad Motora; Caminata; Ciclismo
Submitted on 29/Nov/2016

Final version resubmitted on 09/May/2017 Approved on 01/Jun/2017 